\title{
CHALLENGES FACED BY AUDITORS WHEN ESTIMATING FAIR VALUES. AN EXPERIMENT IN AN EMERGING ECONOMY
}

\author{
Adela DEACONU* \\ Babeș-Bolyai University of Cluj-Napoca, Romania \\ Ioana CIURDAS \\ Babeș-Bolyai University of Cluj-Napoca, Romania \\ Carmen BONACI \\ Babeș-Bolyai University of Cluj-Napoca, Romania
}

\begin{abstract}
Risks related to fair value (FV) estimates and their impact on the audit process represent a crucial topic in accounting and audit literature. Therefore, this paper focuses on one of the influential factors of FV estimation and related risks in audit missions, i.e. the valuation process performed (provider and measurement). In doing so, it addressees a less analysed FV level of estimation - level 3 according to IFRS 13, 'the models', for the case of tangible assets. An experiment is conducted on a group of auditors, members of the Romanian audit professional body. The results reveal that, if the internal control quality is high, auditors differentiate between FV providers in the case of: FV measurement, i.e. income valuation approach versus cost approach, which implies additional effort for verification and risk of misstatement, when the estimation is provided by a third party instead of management. These findings could be related to the volatility of the investigated economic context and the respondents' level of knowledge and expertise. We infer that respondents have a moderate understanding of valuation logic and methodology while excessively relying on their own valuator.
\end{abstract}

Keywords: fair value audit; fair value complexity; estimation risks; fair value provider; tangible asset.

JEL classification: M41, M42, R32, G12.

\footnotetext{
${ }^{*}$ Corresponding author. Address: Department of Accounting and Auditing, Faculty of Economics and Business Administration, Babeș-Bolyai University, Cluj-Napoca, Romania, 400591 Th. Mihali Street 58-60, Tel. +40 264 418655, Fax. +40 264 412570, adela.deaconu@econ.ubbcluj.ro
} 


\section{Introduction}

This paper focuses on the auditor's diligence in verifying accounting estimates, particularly fair value (FV), as the most controversial estimate. Auditors perform specific tests on FV estimates provided by companies' managers, including the assessment of management assumptions on the subject, assumptions' reliability, valuation approaches (methods) and specific inputs used. An appropriately conducted audit process is one of the guarantees for financial reporting quality (Beneish et al., 2012; Zang, 2012; Bolivar and Galera, 2012). Therefore, it is critical to investigate the impact that risks related to FV estimates have on the audit process. The need for such a study is also emphasized by insufficient milestones provided by the literature, audit standards ambiguity, some auditing contexts characterized by market volatility and incomplete adaptation to the international standards' requirements on FV estimation and audit issues.

Among accounting estimates, FV measurement brings forth a unique task due to the recourse to market data, implying greater difficulties when such external information is not immediately available. In order to measure FV, management must use an adequate approach and appropriate assumptions that have the potential to reflect the actions of individuals in the market (Menelaides et al., 2003). The unicity of such an approach is also given by the increasing requirements of accounting standards for the use of FV (Christensen et al., 2012), the complexity of some measurements and their impact on financial statements. In the last years, literature abounds in descriptions and signals of the risks associated with the construction and audit of the estimates. Examples of research topics include valuation inherent risks (e.g. Zack et al., 2009), management opportunism which is sometimes associated with creative accounting techniques (mainly related to earning management) (e.g. Beneish et al., 2012; Zang, 2012), or, generally, estimation uncertainty and implications for audit (e.g. Christensen et al., 2012; Bratten et al., 2013). Nevertheless, there is still room for additional research on audit and estimates (Bratten et al., 2013; Ettredge et al., 2014). Our research attempts to contribute to this debate, specifically related to the risks induced by FV estimation for the audit mission, in an applied approach, all the more so as the current studies do not contain sufficient empirical, but rather more theoretical developments on the subject matter.

Given that professional regulations did not always provide enough guidance in order to minimize the audit risk related to the uncertainty of estimates, researchers call upon standard setters to intervene in this respect. As a response, the audit standard setters are now preoccupied to strengthen requirements for auditing accounting estimates, including FV. They are aware of the nature of estimates, subjective and susceptible to management bias. As our case is built on the Romanian setting, where International Auditing Standards (ISA) are applied, we are mainly interested in the measures taken by the International Auditing and Assurance Standards Board (IAASB).

Romania's case, having an emerging economy, is interesting to explore because it exacerbates some of the FV audit risks due to the market volatility that induces more difficulties in observing relevant market inputs. Thus, as a Central-Eastern European country, Romania has experimented in recent decades with several sets of accounting regulations, successively taking over regulations from continental Europe (more precisely France), aligning with European directives (since 2007), inserting elements of International Accounting Standards (IFRS) in the national 
referential and requiring listed companies to fully apply IFRS (since 2016). Therefore, at this moment, the accounting provisions promote, much more than before, the use of fair value, which brings significant challenges for auditors.

Our study examines one of the influencing factors of FV estimates evoked in literature, namely the FV provider who is the management's expert, a valuator. Investigating this issue is useful as, according to Martin et al. (2006), there is not enough research on how auditors use the services of experts, including the management's ones. Cannon and Bedard (2017) and Glover et al. (2017) also confirm auditors' tendency to significantly rely on the work of external valuation experts. This raises the need for further guidance on how auditors should work with valuators. In our paper, we tackle this topic in the particular setting of an emerging economy. Furthermore, we analyse issues related to the FV provider to cover the entire valuation process offering values to be recognized in financial statements. This contributes to the scarce existing accounting literature.

Our research objective is to observe how the type of valuator, as well as FV measurement/reporting quality influence the audit mission in terms of risk of misstatement and additional effort in the likelihood that auditors request adjustments to FV. We report an experiment with 8 different manipulations where the participants are 76 auditors from Romania. The tests being used are meant to shed light on auditors' use of third party versus management FV estimates of nonfinancial (tangible) assets, conditioning on FV measurement being recognized (cost or income approach) or disclosed (quality of data available to the auditor in the valuation report), all conditional on the quality of internal control.

The main results suggest that auditors expend greater effort when income valuation approach is used instead of cost, and when checking one of the components of FV quality disclosure, i.e. Valuation attributes and sensitivity of data, discerning between the FV provider type (third-party or management estimations), and when internal control quality is strong. We believe that in this way we make a contribution to the specific literature by the extensive investigation of the FV provider in an emergent context which is less explored and for non-financial (tangible) assets, which is a controversial topic in terms of verifiability of FV (Sellhorn and Stier, 2018). Furthermore, we contribute by pointing out the audit risk red flags associated to the entire FV measurement process. Based on the obtained results, we argue for the need for further development of the asset valuation logic and methodology in the auditing process. Last but not least, we invite regulators to continue their actions of clarifying approaches for the valuation of assets in the audit standards, while providing recommendations regarding the verification of the elements with high audit risk potential, especially for more volatile economic contexts and types of assets.

The remainder of the paper is organized as follows: Section 2 synthesizes the relevant literature and audit standards on FV influential factors and valuation process; Section 3 develops the research framework for one of the influential factors, FV estimate provider, extended to other coordinates of the valuation process conducted to estimate the FV; Section 4 describes the application of the experimental method to a group of auditors, members of the Romanian audit professional body, the Chamber of Financial Auditors (CAFR); Section 5 provides insights into the Romanian auditing profession's behaviour regarding the FV estimation process; and the final section discusses and concludes. 


\section{FV estimation process}

\subsection{Influential factors for FV estimation and induced audit risks}

Specific literature has identified several influential factors in the FV estimation audit, those often cited and transposed here in our own words being 'Fair value complexity', 'Estimation uncertainty', 'Managerial bias', 'Professional skepticism', 'Fair value estimate provider', 'Standards guidance', and 'Auditors understanding of the valuation process' (e.g. Bratten et al., 2013 or Doliya and Singh, 2016).

We focus on the influential factor directly related to the valuation process that provides FV, namely 'Fair value estimate provider'. Besides, we extend the area of investigation to the entire process of valuing assets (in our case tangible assets) for financial reporting purposes, adding elements of $\mathrm{FV}$ measurement and reporting. This approach aims at a complete understanding of the interference between property valuation and the audit of these estimates, including audit risks. Therefore, we will further call the selected factor 'Fair value estimation process'. The factor under investigation does not act independently, but in interaction with the others mentioned above. As such, it is necessary that we acknowledge such interactions, our view being illustrated in Figure 1.

Figure 1. FV estimate influential factors. Our approach

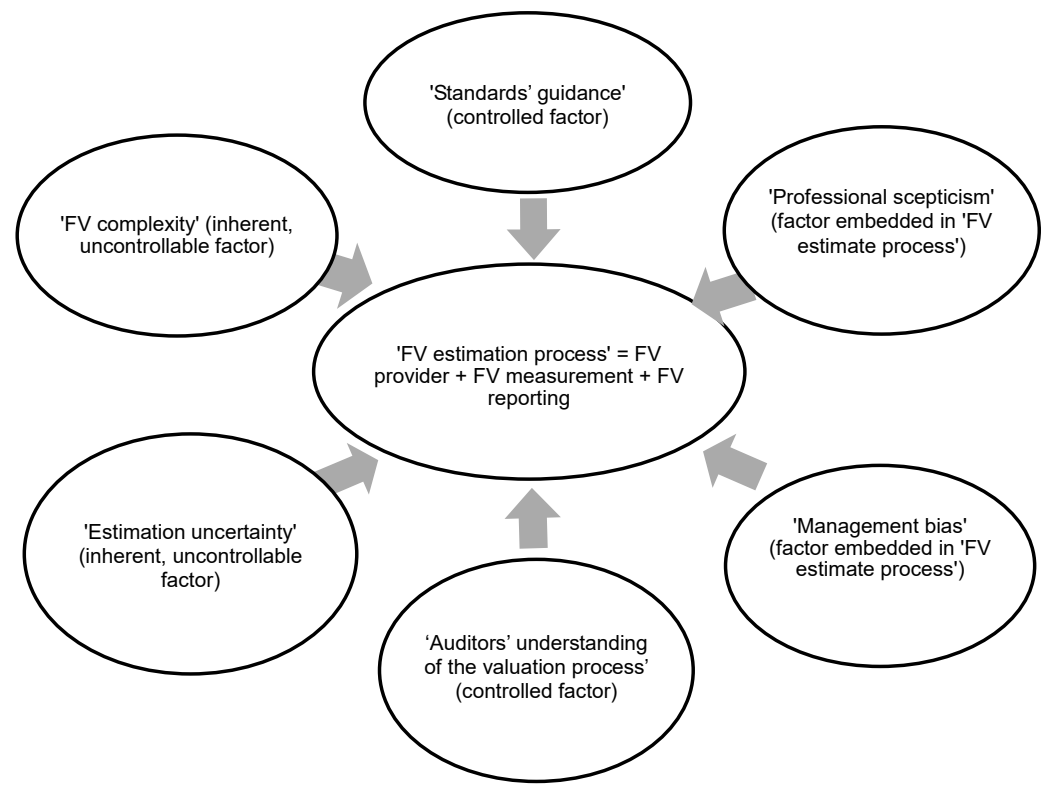

Firstly, 'Fair value complexity' and 'Estimation uncertainty' are viewed as inherent factors, which cannot be controlled, only assumed to occur more or less in different settings. Bratten et al. (2013) describe estimations as an unstructured task of a complex nature, uncertain realisation, which has no objective verifiability. Griffin et al. (2014) measure 'Estimation uncertainty' by inputs volatility (due to subjectivism) 
and outcomes imprecision (the degree of volatility of estimates in the future). In our case, the nature of the assets (non-financial) and the emergent economic context amplify FV estimation complexity and uncertainty.

Secondly, 'Managerial bias' and 'Professional scepticism' are embedded in the selected influential factor, 'FV estimate provider'. 'Managerial bias' covers a type of FV provider, i.e. the management estimation. It is related to management assumptions, which are subjective in nature through the valuation models and inputs selected (Christensen et al., 2012; Bratten et al., 2013; Griffin, 2014; Brink et al., 2016). To adjust management bias effects, Martin et al. (2006) consider that the auditor must know how managers can generate, voluntarily or not, misstatements in FV estimation. 'Professional skepticism' implies a questioning mind and the critical analysis of audit evidence. In the context of the valuation process and professional scepticism, Martin et al. (2006) discuss about: the manner of data collection for the estimation models, i.e. external (more reliable according to Brink et al., 2016), or internal sources; assessing the decision and control process conducted for inputs selection as typology, completeness of available and relevant information, the salience of the inputs; asking questions for the failure to use or lesser weight associated to some potential inputs; the use for his own estimation of other valuation models or inputs than those of the management. Martin et al. (2006) also invoke the auditor's ability to decide if and how the service of external valuators is needed. These suggestions will be transposed in our framework.

Thirdly, the influential factors 'Standards' guidance' and 'Auditors' understanding of the valuation process' are, in our experiment, controlled factors.

When it comes to 'Standards' guidance', we refer to auditing standards that interfere with FV estimate audit. ISA, the standards of interest for us, in their versions up to November 2019, did not offer detailed guidance for auditing specific types of FV estimates (except for derivative instruments, hedging activities and investments in securities), but for understanding management's estimation process and assessing if this conforms to accounting standards. The technical details should be searched for in professional guides and books. Other aspects could still be improved. To date, the updated version of ISA 540 is operational and we will designate it ISA 540 (2019). As a matter of fact, in August 2017, IAASB launched an Exposure Draft on a proposed major revision of ISA 540 Auditing accounting estimates and related disclosures, aiming to enhance requirements for risk assessment procedures and the auditor's work effort in responding to the assessed risks of material misstatement (IAASB, 2017). An interest of IAASB in the use of 'external information sources', which is equivalent to the use of the work of specialists, including valuators, can be observed. The intention is to strengthen the requirements for the auditor to evaluate the work of both management's and auditor's expert (the auditor's expert being the employed and auditor-engaged specialist), including to establish a risk-based approach in such cases. We are interested in the first case, the management's expert, as we will further document. We believe that the factor 'Standards guidance' could be controlled, depending on the setting and the specific case under observation, and we further incorporated these prescriptions in our case materials.

As for the influential factor 'Auditors' understanding of the valuation process', Bratten et al. (2013) think that the lack of auditors' valuation knowledge, explicable due to the complexity of FV, is one of the elements affecting the audit process performance and auditors' ability to find and incorporate in their judgement management bias in FV estimation. IAASB, in ISA 540 (2019), highlights the need for specialized skills or knowledge earlier in the auditing process, in relation to either the understanding or 
the identification and evaluation of the risks of material misstatement. We, therefore, consider this factor as a controlled one, due to the possibility of asserting its level, as our experiment will reveal.

\subsection{Valuation process}

This section focuses on valuation as the process that concludes on FV estimation, namely on FV provider, FV measurement, and FV disclosure. The section is the result of the literature review and international audit standards on the matter. Literature provides a list of potential positive and negative effects of the FV provider. This enables us to design the experiment that will confirm/infirm these theoretical or empirically demonstrated assertions in earlier research. ISA (2019) recommends to the auditors the verification steps in the case of FV estimate, also useful for our case materials.

Referring to the FV estimate provider, it is important to delimitate our area of inquiry. This is because both management and auditors can resort to third parties - valuation experts, in order to build FV estimates or obtain audit evidence on the subject. ISA 500 Audit evidence and ISA 620 Using the work of an auditor's expert make a clear distinction between management's valuation and the auditor's own valuation, in terms of expertise. Thus, management's expert work is used by the auditee to assist him in preparing the financial statements, while auditor's expert work is used by the auditor to assist him in obtaining sufficient appropriate audit evidence. Similarly, ISA 540 (2019) states that management may have, or the entity may employ individuals with the skills and knowledge necessary to make the accounting estimates; and in some cases, management may need to engage an expert to make, or assist in making the estimations (IAASB, 2017). In his turn, the auditor's expert may be either an internal expert (partner or staff of the audit firm or a network firm), or an external expert.

In our approach, we deal with the case of the auditee's valuator, both in the case of a valuation generated internally by the auditee (auditee's management estimation), and of an estimation provided by an external consultant of the auditee (auditee's management's expert). This is because we believe that the work of the valuator who assists the auditor - the auditor's expert according to ISA 620, is integrated into the audit process' global effort. Besides that, the efforts of the auditor differ in magnitude and nature when he verifies the valuation provided by the auditee versus when he evaluates the adequacy of his own expert's work. We chose to focus on the most demanding task for the auditor, which has the potential to pose the higher risks for the audit of estimates. Additionally, we will include in our investigation the possibility that the auditor resorts to its own valuator, if that approach impacts auditors' perceptions in our experiment. In this respect, regulators, such as PCAOB (2011) and SEC (2011), are concerned about the auditors' tendency to focus excessively on valuators' reports, neglecting their own verification steps or audit procedures.

Focusing on the issue of FV provider, analysed in relevant papers, it seems that in terms of its effects, the use of a valuation expert apparently reduces the audit risk. There are studies asserting that the reliability of FV estimate increases for the investors when valuation experts' services are used (e.g. Muller and Riedl, 2002; Bratten et al., 2013). This opinion is shared by the American and international auditing standard setters, PCAOB (2014) and IAASB (2018). Using an external 
valuator instead of an internal one (management's expert) impacts the valuation process and is considered more objective by Barth and Clinch (1999) and King (2006). Brink et al. (2016) also argue that FV estimation is less risky if generated by an external source. Sellhorn and Stier (2018) conclude that an external valuator's involvement enhances the decision usefulness of FV.

On the other hand, Joe et al. (2017) warn about weaknesses if the data disclosed in the valuation report are significant in quantity, in the case of a high risk of the client's internal control. In this case, the auditor is inclined not to proceed to additional tests, such as checking the subjective inputs, but rather focusing on other details and objective inputs. Also, sometimes auditors do not have access to the particular data used by valuators as inputs for constructing the value, such as, for example, proprietary specific data (Glover et al., 2014; Cannon and Bedard, 2017). Goncharov et al. (2014) formulate the hypothesis that the use of a valuation expert reduces the audit risk in correlation with audit fees supposed to decrease as the auditor effort also decreases. The later study failed to obtain statistically significant results.

As documented, divergent opinions arise on engaging an external valuation expert and its effects on the audit process. Hence, we intend to verify these assertions for the particular setting of our study.

Other issues to characterize FV estimation process, apart from the FV provider effects described above, are linked to the valuation report/document prepared by a third-party or management, which we will consider in our framework.

According to the literature, auditors tend to verify in detail the values provided by valuation reports, if there is an adequate disclosure, mainly estimated by valuation experts (Salzsieder, 2016), reducing management opportunism, as Abernathy et al. (2015) claim. The nature and volume of the tests that auditors will perform to verify FV are influenced by the valuation report content, in the case of a weak internal control of their client (Brown-Liburd et al., 2014; Joe et al., 2017).

In the view of regulators, following the standard's risk assessment procedures, the auditor should obtain an understanding of how management identifies the relevant methods, assumptions, or sources of data, as well as the need for changes in them [ISA 540 (2019), para. 13 (h (ii (a)))]. This includes how management selects or designs, and applies, the methods (including the use of models), selects the assumptions (including consideration of alternatives and identification of significant assumptions) and selects the data to be used. Furthermore, it is important to know how management understands the degree of estimation uncertainty and addresses it [ISA 540 (2019), para. 13 (h (ii (b,c)))]. Para. 13 (f) in ISA 540 (2019) addresses the understanding of how management identifies the need for, and applies, specialized skills or knowledge (including the use of an expert), while para. 13 (g) focuses on the entity's risk assessment process in identifying and addressing risks. The auditor should consider indicators for possible management bias and their implications for the audit [ISA 540 (2019), para. 32].

\section{Experimental design}

\subsection{Variables and framework}

In our framework, the dependent variables, inspired by other experimental studies in audit literature (Griffin, 2014; Brink et al., 2016) are Likelihood that the auditor develops additional effort to further investigate the FV estimate and Higher risk of misstatement of FV estimation. They suggest the magnitude of risk of misstatement 
that the participants will assess, as well as the additional time and effort needed to investigate FV measurement and reporting, depending on the FV provider (third party or management estimation) in the likelihood that auditors request adjustments to FV.

The independent variables are built, as Table 1 shows, according to prior literature, using the new institutional setting (ISA 540), but also our own logic on the importance of the valuation process and verifiable components. The literature on FV estimation influential factors has reported the first of the variables, the FV provider, with mixed results in terms of its effects. Also, other papers provided some hints on the importance of internal control quality, which we found useful to investigate. Furthermore, we developed one other variable for FV measurement. We started from the quantifiable elements suggested to auditors through ISA 540 (2019) when verifying an accounting estimate for a financial statement item, i.e. the relevant quantitative and qualitative valuation attributes and the sources of data that would provide appropriate measures of those attributes. We also used ISA 540 (2019)'s recommendations on the steps to verify accounting estimates as references for the minimal requirements of a valuation report, adding some elements judged as relevant for assessing FV measurement accuracy.

Table 1. Choices for the independent variables

\begin{tabular}{|c|c|}
\hline Independent variables & Condition \\
\hline 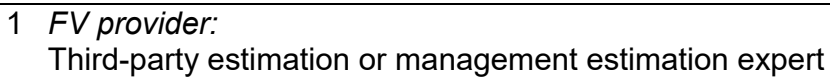 & \multirow[b]{2}{*}{$\begin{array}{l}\text { quality of the internal } \\
\text { control of the auditee } \\
\text { (week or strong) }\end{array}$} \\
\hline $\begin{array}{l}2 \text { FV measurement: } \\
\text { Volume and type of quantitative data in the content of } \\
\text { the valuation report }\end{array}$ & \\
\hline
\end{tabular}

Within our framework, the independent variables have a particular content which will shape our experimental propositions.

The first variable, FV provider, suggests a third-party (external valuator, consultant) or management's estimation (internal valuator). For the Romanian context, both the external valuator and the internal valuator are required to be approved as members of ANEVAR, the national professional association. In these circumstances, we expect fewer evaluation cases through the company's internal staff due to the complexity of the valuation tasks and the specific professional requirements, and thus barriers to becoming an authorized valuator.

The second variable refers to FV measurement, which we expressed as a specific valuation approach applied, income or cost, considering that we chose IFRS level 3 of FV estimation (the models) for the experiment. The two approaches denote, in our view, a difference in volume and type of inputs. The volume of inputs will also be suggested in the experiment matrix when FV measurement is combined with FV provider; the volume of data is more significant in the Valuation document provided by a third-party instead of management. The income approach is more linked to market inputs and more predictive data than the cost approach, which uses more historical data combined with current (market) data. Our arguments for choosing Level 3 to be tested are based on the fact that, in Romania, only real estate is usually evaluated for financial reporting, tax and loan guaranteeing purposes. The approaches used in these cases are generally income and cost, and not market approach, if the 
assets were not for sale (Level 2 in the value hierarchy). The financial instruments, which could be evaluated at the Levels 1 and 2, require extremely rare evaluations. Furthermore, we chose the income and cost approaches applied to real estate, as we consider these were so far neglected in the fair value accounting literature. Barker (in Mora et al., 2018) believes that measurement concepts applicable to operating versus financial assets should be differentiated within the international accounting referential (Conceptual framework and IFRS 13). One of his arguments is that in terms of verifiability, level 3 fair values are more difficult to verify than level 1 . This provides us with the opportunity to bring insights on the subject.

For all these variables, we introduced a condition under the form of the internal control quality, a component of the audit process. Table 2 presents the proposed research framework.

Table 2. Experiment's framework

\begin{tabular}{|c|c|c|c|}
\hline \multirow{2}{*}{$\begin{array}{l}\text { Quality of } \\
\text { internal } \\
\text { control }\end{array}$} & \multirow[b]{2}{*}{$\begin{array}{l}\text { FV measurement: } \\
\text { Volume and type of data in } \\
\text { the Valuation Document }\end{array}$} & \multicolumn{2}{|c|}{ FV provider } \\
\hline & & $\begin{array}{l}\text { Third-party } \\
\text { estimation }\end{array}$ & $\begin{array}{l}\text { Management's } \\
\text { estimation }\end{array}$ \\
\hline \multirow{2}{*}{$\begin{array}{l}\text { Week/ } \\
\text { Strong }\end{array}$} & $\begin{array}{l}\text { Focus on predictive data in the } \\
\text { construction of the variables } \\
\text { (income approach) }\end{array}$ & $\begin{array}{l}\text { Typical valuation } \\
\text { report } \\
\text { Data concerning } \\
\text { level } 3 \text { of FV }\end{array}$ & $\begin{array}{l}\text { Management's } \\
\text { valuation } \\
\text { worksheet for the } \\
\text { estimation; } \\
\text { Data concerning } \\
\text { level } 3 \text { of } \mathrm{FV}\end{array}$ \\
\hline & $\begin{array}{c}\text { Focus on historical and current } \\
\text { data in the construction of the } \\
\text { variables } \\
\text { (cost approach) }\end{array}$ & $\begin{array}{l}\text { Typical valuation } \\
\text { report } \\
\text { Data concerning } \\
\text { level } 3 \text { of FV }\end{array}$ & $\begin{array}{l}\text { Management's } \\
\text { valuation } \\
\text { worksheet for the } \\
\text { estimation; } \\
\text { Data concerning } \\
\text { level } 3 \text { of FV }\end{array}$ \\
\hline
\end{tabular}

- Valuation Document designates both the valuation report of the external expert in the standard format agreed by his professional association (ISA 500 includes a stipulation on the use of analysts' reports, as information from a source independent of the entity), and the management specific documents provided as justification for FV measurement.

With reference to the direction of the relationships between variables, we formulate the following empirical prediction $(P)$ :

P: Auditors distinguish between the use by the management of a third party versus an internal valuation, and consider that a third party valuation decreases the estimation risk and audit effort, when income approach is applied instead of cost approach for FV measurement and when the internal control quality is strong. 
In the above prediction, the choice of internal control as strong in quality is justified by the fact that, in this case, the auditors focus on the significance of the valuation approaches as solutions for measuring FV (cost, income), respectively on the disclosure of the elements of the valuation process.

Our expectations related to other FV estimation influential factors which were presented in Figure 1 and accompany these predictions, are further presented.

'Managerial bias' and 'Professional scepticism' as FV estimate influential factors are embedded in these propositions.

For the Romanian setting, we assume that 'Fair value complexity' is higher for the real estate valuation and level 3 of FV estimation than for other types of assets and levels of estimation (1 and 2). Also, we believe that 'Estimation uncertainty' is higher, as the markets (financial markets generally and the real estate market) are volatile and less liquid compared to those in developed economies. These two factors are considered in our framework as uncontrollable, existing factors.

For the factor 'Standards' guidance', which is viewed in our framework as a controlled factor, we inserted the new provisions of ISA 540 (2019) in the experiment cases in order to eliminate the potential lack of professional guidance and thus control the auditors' judgements and directing them towards FV estimate process issues.

The factor 'Auditors understanding of the valuation process' is a controlled factor and our expectations are for a moderate understanding. In fact, the valuation profession has its own challenges, competencies and experience related requirements. This profession is guided by a set of specific standards, professional guides and specific literature. Besides, ISA and IFRS requiring FV use have been mandatory in the last 10 years, reason for which the auditors' expertise in fair value issues is relatively new. Also, the cases requiring FV estimation are not as common as in developed economies. In our paper, the frequency of such cases will be observed in the demographic test. Finally, we wonder if the auditor's use of his own valuator will affect his judgment and interfere with the perception on the valuation provider, respectively on the FV measurement and reporting. Brink et al. (2016), in their study of the Chinese emergent market, expect the auditor to resort to his superior or to a peer for advice, due to the FV complexity and high uncertainty. We thought that it is reasonable to assume that the participants resorted to the advice of a valuator - especially in the Romanian context, where we assume a lack of valuation competencies - and we are interested in the overall effort to analyse the report/valuation worksheet (auditor, plus his expert).

\subsection{Case materials}

The independent variables are of between-participants type, all integrated in a $2 \times 2$ experimental design. We created 4 cells as interactions between FV estimate provider and FV measurement, each interaction being doubled for the case of weak internal control and strong internal control as quality. Table 3 below illustrates our logic and also includes detailed descriptions. 


\begin{tabular}{|c|c|c|}
\hline \multirow{3}{*}{ FV measurement and reporting } & \multicolumn{2}{|c|}{ FV provider } \\
\hline & $\begin{array}{c}\text { Use of a } \\
\text { third-party } \\
\text { (Valuation } \\
\text { Report) }\end{array}$ & $\begin{array}{c}\text { Management's } \\
\text { estimation } \\
\text { (Management } \\
\text { Valuation } \\
\text { Worksheet) }\end{array}$ \\
\hline & $\begin{array}{l}\text { Conditione } \\
\text { internal cont }\end{array}$ & $\begin{array}{l}\text { the quality of } \\
\text { week or strong } \\
\text { d b) }\end{array}$ \\
\hline
\end{tabular}

FV measurement: Volume and type of quantitative data in the Valuation Document

Case material 1 - a standard and comprehensive Valuation Report or Management Valuation Worksheet (hereafter Valuation Document 1) containing a valuation based on the income approach; suggestions on checks are made to participants":

- How the inputs for Level $3^{\text {** }}$ in the value hierarchy were found and if they represent the assumptions that market participants would use;

- Particularly (for the income approach):

$\checkmark$ Whether the estimation of fair value was based on rents or quotations from an active market;

$\checkmark \quad$ If the estimation of fair value was based on the listing of a real estate agency, if it comes from a similar market and if it reflects the market conditions.

Case material 2 - the Valuation Document 1, modified, containing a valuation based on the cost approach; suggestions on checks are made to participants":

- How the inputs for Level $3^{* *}$ in the value hierarchy were found and if they represent the assumptions that market participants would use.

- Particularly (for the cost approach):

$\checkmark$ How were the input data obtained and whether these represent the assumptions that market participants would use;

$\checkmark \quad$ If the estimate of the gross replacement cost and of the depreciation is sufficiently substantiated.

\section{Case $\mathrm{A} / \mathrm{a}, \mathrm{b} \quad$ Case $\mathrm{B} / \mathrm{a}, \mathrm{b}$}

\section{Case $\mathrm{C} / \mathrm{a}, \mathrm{b} \quad$ Case $\mathrm{D} / \mathrm{a}, \mathrm{b}$}

*inspired from ISA 540 (2019), section Risk assessment procedures and related activities, Application and others explanatory material: A40-41 and A 127-129 and respectively Appendix 1;

* the approaches supposed by Level 3 (income, respectively cost); income approach is supposed to incorporate more predictive data than cost approach which uses historical and current data; also, income approach is supposed to use less subjective inputs than cost approach. 
For all the cases, we provided participants with experimental materials three versions of a valuation report designed to capture the elements to test. We titled the report 'Valuation Document'. The Valuation Document is an adaptation of a real Valuation Report obtained from a prestigious local firm specializing in property valuation. The report was made according to the valuation standards applicable in Romania, SEV, prescribed by ANEVAR, similar to the International Valuation Standards (IVS) and to professional customs, including, for example, valuator certification or limitative conditions. We first removed all the data that could divulge the valuator, his client and the property being subject to valuation. Then, we manipulated the Report according to our intentions as revealed in Table 3. Therefore, we replicated this Valuation Report (cases A, C) into a Management Valuation Worksheet in order to obtain the experimental materials for the cases $B$ and D. Then, we adjusted the same Valuation Report in order to reveal as the valuator's opinion only one of the values and approaches applied in the valuation process, either income (cases A, B), or cost approach (cases C, D). An excerpt of the Valuation Report is provided in Appendix 1 (for the case A/cell A, as example).

For the item 'Volume and type of quantitative data in Valuation Document' (FV measurement), we provided, apart from the Valuation Document, a list of auditor steps to verify FV estimate, according to ISA 540 (2019), as measurement checks related to the nature of the valuation approaches used, and then as reporting, checks related to inputs, methods and assumptions made for the measurement. In order to simplify the presentation, according to Table 3, we will designate the cases for FV measurement as Income approach versus Cost approach.

In our discussions with the respondents, we made a brief reference to internal control, mentioning that it can be differentiated by features such as: existence of separation of tasks for the specialized personnel, existence of all supporting documents, existence of written procedures and policies for all activities.

Both dependent variables were quantified by the participants on a 7-point Likert scale, anchored by 1 (very low likelihood of a higher risk of misstatement/ developing additional effort, and 7 (very high likelihood of a higher risk of misstatement/ developing additional effort).

For the variable 'Higher risk of misstatement of FV estimation', we recommended to participants that they link their assessment to ISA 540 (2019)'s requirements in the case of risk assessment procedures and related activities. As response to the assessed risks of material misstatement, the standard specifically recommends, in order to face the complexity, judgement (management bias) and estimation uncertainty, the following checks: whether the method and significant data and assumptions are appropriate in the context of the applicable financial reporting framework; whether significant data is relevant and reliable; whether management has properly understood or interpreted significant data; whether the integrity of significant data and assumptions has been maintained in applying the method; whether the calculations are mathematically accurate and appropriately applied; when management's application of the method involves complex modelling, whether judgements made have been applied consistently, the design of the model meets the measurement objective and is appropriate in the circumstances; if changes of the models of the previous period or adjustments to the output of the model are appropriate; when management has not appropriately addressed the estimation uncertainty, the auditor shall develop a point estimate or range. 
In order for the participants in the experiment to better understand the variable 'A higher risk of misstatement of FV estimation', we also recommended them to consider the likelihood that the auditor that is the character in our case materials requires value adjustments. Appendix 1 Measurement bases of accounting estimates, para. 8 of ISA 540 (2019) provides a suggestion in the context of making an estimate. This is the nature and extent of any adjustments that may be made to the estimate arising from the application of method(s) used to build the estimate, for example to reflect practical limitations in the validity of the valuation technique(s) used in measuring what it purports to measure.

For the variable 'Likelihood that the auditor develops additional effort to further investigate the FV estimate', we recommended that participants associate the additional effort with additional audit procedures during both the risk assessment phase and the gathering of audit evidence one. We also offered details of ISA 540 (2019) in the case materials, starting from one requirement of the extant ISA 540 (2019), i.e. to test how management (or its expert, we added) made the accounting estimate and the data on which it is based. ISA 540 (2019) adopted a control-based approach, much more applied and expanded than the extant ISA 540.

The case materials were reviewed with two experienced auditors and, after some clarifications, we proceeded to a pilot test with 160 first-year Master students, specializing in audit, accounting and, diagnosis and property valuation. The students had completed at the bachelor's and master's level two courses in the field of auditing and two other courses in the field of valuation of assets and companies, attesting their competencies in the field of our research study. Some refinements were made on case materials, as form of presentation. Also, we noticed the need to introduce a prior verification of the understanding of the central concepts of our study (as Appendix 2 presents).

\subsection{Participants}

The experimental materials have been applied through direct meetings within the regular workshops of the auditors registered under the Chamber of Financial Auditors in Romania (CAFR). The applications were carried out successively, in the period September - November 2019 in two meetings organized within two regional branches, located in representative cities from Romania, Transylvania region. The experiment subjects were assigned randomly, counting, overall, 76 participants. Each person filled two case materials, the type of the valuation document (Valuation Report of a third-party or Management Valuation Worksheet), as well as the type of internal control quality (weak or strong) being identical. We believe that our test is sufficiently powerful compared to our possibilities of obtaining data and other experimental studies in audit that involved between 97 and 106 participants (Earley et al., 2008; Griffin, 2014; Brink et al., 2016).

Before the experiment began, we performed some manipulation checks to verify the auditors' understanding of the issues investigated, namely FV provider and the level of the FV in the value hierarchy, associated with the valuation approaches. An excerpt from this preliminary case study, as we named it, is presented in Appendix 2. The results were satisfactory (almost all of the auditors provided accurate answers for FV provider and about $70 \%$ for the valuation approaches 
associated to value levels). Considering the second part of these results, we continued to process the data in order to view the extent to which auditors rely on valuators or on their own knowledge in the field of real estate valuation methodology.

In the last part of the meetings, we asked the participants to fill in a short demographic survey. It has integrated variables related to the way auditors practice their profession (independently or within an audit firm), their position within the audit firm (partner, manager, senior or junior), experience in the audit profession as number of years, experience in FV auditing as number of cases / reports, frequency of training courses on FV (for the whole of their activity), respectively, if they have used the services of a valuator (internal, of the audit firm, or external) (for the whole of their activity). Specifically, for our experiment, we checked if the group of auditors has enough valuation expertise to understand the valuation process and if they used their own valuator.

Table 4 presents the form in which auditors practice the profession, respectively their general experience in audit and fair value matters.

Table 4. Descriptive statistics for auditors' main characteristics

\begin{tabular}{|c|c|c|c|c|c|c|c|}
\hline & \multicolumn{7}{|c|}{ Position } \\
\hline & & $\begin{array}{l}\text { Partner } \\
(n=32)\end{array}$ & $\begin{array}{c}\text { Manager } \\
(n=10)\end{array}$ & $\begin{array}{l}\text { Senior } \\
(n=10)\end{array}$ & $\begin{array}{l}\text { Junior } \\
(n=6)\end{array}$ & $\begin{array}{c}\text { Other } \\
\text { situations } \\
(n=2)\end{array}$ & $\begin{array}{l}\text { Overall } \\
(n=76)^{*}\end{array}$ \\
\hline \multicolumn{8}{|l|}{ Affiliation** } \\
\hline Independent & No. of & 13 & 4 & 2 & 0 & 0 & 19 \\
\hline Audit firm & cases & 19 & 6 & 8 & 6 & 2 & 41 \\
\hline \multicolumn{8}{|l|}{$\begin{array}{l}\text { Audit experience } \\
\text { (years) }^{* *}\end{array}$} \\
\hline $1-5$ years & No. of & 2 & 2 & 6 & 6 & 0 & 16 \\
\hline $5-10$ years & cases & 14 & 4 & 0 & 0 & 0 & 18 \\
\hline$>10$ years & & 16 & 4 & 4 & 0 & 2 & 26 \\
\hline \multicolumn{8}{|l|}{$\begin{array}{l}\text { Fair value audit } \\
\text { experience }{ }^{* *}\end{array}$} \\
\hline Less than 15 cases & No. of & 26 & 10 & 8 & 6 & 2 & 52 \\
\hline More than 15 cases & cases & 6 & 0 & 0 & 0 & 0 & 6 \\
\hline \multicolumn{8}{|l|}{$\begin{array}{l}\text { Training on FV } \\
\text { subject } * *\end{array}$} \\
\hline Yes, often & No. of & 4 & 0 & 2 & 0 & 0 & 6 \\
\hline Yes, occasionally & cases & 16 & 8 & 6 & 2 & 0 & 32 \\
\hline No & & 12 & 2 & 2 & 4 & 2 & 22 \\
\hline \multicolumn{8}{|l|}{$\begin{array}{l}\text { Appeal to auditor's } \\
\text { own valuator** }\end{array}$} \\
\hline Frequently & No. of & 12 & 2 & 0 & 0 & 0 & 14 \\
\hline Occasionally & cases & 16 & 4 & 4 & 0 & 2 & 26 \\
\hline Never & & 4 & 4 & 6 & 6 & 0 & 20 \\
\hline
\end{tabular}

*16 missing information for certain variables; **auditors were advised to judge the criterion for the last five years of their activity. 
The majority of the 76 auditors have more than 10 years of experience in audit. However, for the Romanian context, we observed a limited fair value audit experience of our participants, less than 15 cases in their whole activity being the prevailing response. Another indicator of the relatively modest knowledge in valuation issues is the high percent, $90 \%$ of cases, in which auditors had only occasional trainings on FV matters or not at all. This observation is consistent with the results for the last two descriptive items related to the frequency of fair value trainings and the use of their own valuator. The auditors seem to resort quite often to a valuation expert (for $23 \%$ of cases frequently and for other $43 \%$ occasionally).

\section{Research findings}

As statistical tests proposed, those correlated to our aim are descriptive statistics, univariate and multivariate analysis and, respectively, mean values and simple effects test.

\subsection{Multivariate and univariate analysis}

We started our statistic tests with the multivariate analysis (three-way MANOVA) in order to see if there is an interaction effect between our three independent variables ( $F V$ measurement/FV reporting, FV provider and Internal control) on the two continuous dependent variables ('Likelihood that the auditor develops additional effort to further investigate the FV estimate' and 'A higher risk of misstatement of FV estimation'). The variables FV measurement and FV reporting are complementary and hence we ran a test for each one. We wanted to see whether the effect of FV provider on the dependent variables taken together is dependent on the value of the other independent variable: FV measurement/FV reporting and Internal control, the results being shown in Table 5 .

Table 5. Multivariate analysis results (three-way MANOVA)

\begin{tabular}{lcccc}
\hline \multicolumn{1}{c}{ Independent variables } & $\begin{array}{c}\boldsymbol{F}(\text { Wilk's } \\
\boldsymbol{k})\end{array}$ & $\begin{array}{c}\boldsymbol{p} \text { - } \\
\text { value }\end{array}$ & $\begin{array}{c}\text { Partial } \\
\boldsymbol{\eta} \mathbf{2}\end{array}$ & $\begin{array}{c}\text { Observed } \\
\text { Power }\end{array}$ \\
\hline FV measurement & 0.610 & 0.546 & 0.018 & 0.148 \\
FV provider & 6.241 & $\begin{array}{c}0.003^{* *} \\
*\end{array}$ & 0.161 & 0.881 \\
Internal control quality & 9.302 & $\begin{array}{c}0.000^{* *} \\
*\end{array}$ & 0.223 & 0.973 \\
FV measurement x FV provider & 2.035 & 0.139 & 0.059 & 0.405 \\
FV measurement x Internal control quality & 3.689 & $0.030^{* *}$ & 0.102 & 0.658 \\
FV provider x Internal control quality & 2.333 & 0.105 & 0.067 & 0.456 \\
FV provider x FV measurement x Internal & 1.931 & 0.153 & 0.056 & 0.387 \\
\hline
\end{tabular}

'between 'Likelihood that the auditor develops additional effort to further investigate the FV estimate' and 'A higher risk of misstatement of FV estimation' as dependent variables, respectively all the independent variables; the tests for FV measurement and FV reporting were run separately

${ }^{* * *},{ }^{* *},{ }^{*}$ significant at $1 \%, 5 \%$, respectively $10 \%$

Notes: Partial $\eta 2$, measured on a scale of 0 to 1 , indicates the proportion of the variance in the dependent variables explained by the independent variables; Observed Power, measured on a scale of 0 to 1 , indicates the likelihood that an effect will be detected. 
Overall, according to Partial $\eta 2$ Test, the variables FV provider and Internal control quality - independently, respectively FV measurement - in combination with these first variables, have a significant contribution in explaining the variance of the model, meaning an effect on the additional effort to verify FV estimate and on the risk of misstatement in FV estimation. The statistical significance denoted by $p$ value and the values of Observed Power test confirms these results.

Our next step was to determine if there is an interaction effect between our three independent variables on the dependent variables (each one taken separately). The results for the dependent variable 'Likelihood that the auditor develops additional effort to further investigate the FV estimate' are presented in Table 6.

Table 6. Univariate analysis (three-way ANOVA)

\begin{tabular}{lcccc}
\hline \multicolumn{1}{c}{ Independent variables } & $\begin{array}{c}\text { Sum of } \\
\text { squares }\end{array}$ & $d f$ & $F$ & $p$-value \\
\hline FV measurement & 0.647 & 1 & 0.389 & 0.535 \\
FV provider & 0.060 & 1 & 0.036 & 0.850 \\
Internal control quality & 28.635 & 1 & 17.223 & $0.000^{* * *}$ \\
FV measurement x FV provider & 6.519 & 1 & 3.921 & $0.052^{*}$ \\
FV measurement x Internal control & 9.259 & 1 & 5.569 & $0.021^{* *}$ \\
FV provider x Internal control & 4.855 & 1 & 2.920 & $0.092^{*}$ \\
FV provider x FV measurement x Internal & 3.974 & 1 & 2.390 & 0.127 \\
control quality & & & & \\
\hline
\end{tabular}

$R$ Squared $=0.331 ;$ Adjusted $R$ Squared $=0.260$

- with 'Likelihood that the auditor develops additional effort to further investigate the FV estimate' as dependent variable

${ }^{* * *},{ }^{* *},{ }^{*}$ significant at $1 \%, 5 \%$, respectively $10 \%$.

The analysis related to FV measurement reveals the significance of the internal control quality $(p=0.000)$ for the auditor's effort. It looks like the valuator type (external or internal) and the valuation process per se suggested by FV measurement do not significantly impact the auditors, in terms of additional audit effort, if these variables are taken independently. Thus, FV provider is important for the auditors when it is linked to FV measurement approaches (income, cost) $(p=0.052)$; and also when the quality of the internal control is added to these combinations. The internal control quality is also determinant when the auditor focuses on FV measurement without considering the valuator type (FV provider) $(p=0.021)$.

We also ran the univariate analysis for the other dependent variable, 'A higher risk of misstatement of FV estimation' and the untabulated statistics are similar in terms of results.

\subsection{Mean values and test of simple effects}

We continued our analysis with other tests to see whether there were differences in auditors' assessed level of 'Likelihood that the auditor develops additional effort to further investigate the FV estimate' based on FV provider type, quality of the internal control and FV measurement. Table 7 reveals the perceptions of auditors on the Likert scale (as mean values) and the effects on the dependent variable. 
Table 7. Means and simple effects

\begin{tabular}{|c|c|c|c|}
\hline \multicolumn{4}{|c|}{ Panel A - related to FV measurement - when the quality of internal control is week } \\
\hline \multicolumn{4}{|c|}{ FV provider } \\
\hline FV reporting & $\begin{array}{l}\text { Use of third-party } \\
\text { estimation }\end{array}$ & $\begin{array}{l}\text { Management's } \\
\text { estimation }\end{array}$ & $\begin{array}{l}\text { Test of simple } \\
\text { effects }\end{array}$ \\
\hline \multirow[t]{3}{*}{ Income approach } & $4.67^{\mathrm{a}}$ & 5.00 & $\mathrm{~F}=0.298$ \\
\hline & $(0.541)^{\mathrm{b}}$ & $(0.365)$ & $p=0.588$ \\
\hline & $\mathrm{n}=12$ & $n=10$ & \\
\hline \multirow[t]{3}{*}{ Cost approach } & $4.00^{\mathrm{a}}$ & 4.60 & $\mathrm{~F}=0.665$ \\
\hline & $(0.632)^{b}$ & $(0.267)$ & $p=0.421$ \\
\hline & $\mathrm{n}=6$ & $\mathrm{n}=10$ & \\
\hline \multirow{2}{*}{$\begin{array}{c}\text { Test of simple } \\
\text { effects }\end{array}$} & $\mathrm{F}=0.875$ & $\mathrm{~F}=0.394$ & \\
\hline & $p=0.356$ & $p=0.534$ & \\
\hline \multicolumn{4}{|c|}{ Panel B - related to FV measurement - when the quality of internal control is strong } \\
\hline \multicolumn{4}{|c|}{ FV provider } \\
\hline FV reporting & $\begin{array}{c}\text { Use of third-party } \\
\text { estimation }\end{array}$ & $\begin{array}{c}\text { Management's } \\
\text { estimation }\end{array}$ & $\begin{array}{c}\text { Test of simple } \\
\text { effects }\end{array}$ \\
\hline \multirow[t]{3}{*}{ Income approach } & $3.67^{\mathrm{a}}$ & 2.00 & $\mathrm{~F}=10.492$ \\
\hline & $(0.414)^{b}$ & $(0.267)$ & $p=0.003^{* * *}$ \\
\hline & $\mathrm{n}=12$ & $\mathrm{n}=8$ & \\
\hline \multirow[t]{3}{*}{ Cost approach } & $3.50^{\mathrm{a}}$ & 4.00 & $\mathrm{~F}=0.787$ \\
\hline & $(0.327)^{\mathrm{b}}$ & $(0.378)$ & $p=0.382$ \\
\hline & $\mathrm{n}=8$ & $n=8$ & \\
\hline \multirow{2}{*}{$\begin{array}{l}\text { Test of simple } \\
\text { effects }\end{array}$} & $F=0.105$ & $\mathrm{~F}=12.590$ & \\
\hline & $p=0.748$ & $p=0.001^{* * *}$ & \\
\hline
\end{tabular}

- with 'Likelihood that the auditor develops additional effort to further investigate the FV estimate' as dependent variable

${ }^{\mathrm{a}}$ mean; ${ }^{\mathrm{b}}$ standard error

${ }^{* * *},{ }^{* *},{ }^{*}$ significant at $1 \%, 5 \%$, respectively $10 \%$

The results show that only if the internal control is strong as quality, the auditors really differentiate the FV issues (Panels $B$ and $D$ ). Therefore, the cases when the quality of internal control is weak, do not present statistical relevance as differentiated perceptions (Panels $A$ and $C$ ), but the mean values suggest a preference for a third party valuation, the management's estimation requiring more audit effort, independently of the valuation approaches applied or the issues of the valuation process disclosure quality.

When the quality of internal control is higher, it can be observed from panel $B$ that the FV provider has an impact on the possible effort that the auditor is going to make in order to investigate more the FV estimate, for one of the valuation approaches, income approach that use predictive inputs $(p=0.003)$, but in the sense of an additional effort of verification (mean of 3.67 for the use of a third-party versus 2 for the management estimation). Also, auditors differentiate better between the two valuation approaches when it comes to the management 
estimation $(p=0.001)$, instead of a third party valuation. For this situation, the probability of additional effort increases in the case of cost approach compared to income approach, according to the mean values (mean of 4 for cost approach versus 2 for income approach).

Untabulated statistics revealed similar results when we changed the dependent variable, using 'A higher risk of misstatement of FV estimation' instead of 'Likelihood that the auditor develops additional effort to further investigate the FV estimate'. These results can be seen as robustness tests, supporting our data quality and auditors' message.

\section{Discussion}

A first observation is that the multivariate and univariate analysis (Tables 5 and 6) provide a first clue about the importance of Internal control quality, FV provider and FV measurement in relation to auditors' additional effort to verify FV estimate and higher risk of misstatement of FV estimation. The variable Internal control quality acts independently and this outcome is explicable knowing the relevance of this issue for the audited company in relation to the entire audit process. The variables FV provider and FV measurement act in combination between them and Internal control quality in order to generate a reaction on the auditor's part. These results confirm our choice to link auditors' perception with the internal control quality and the relevance of the investigation of the valuator type (third-party or management).

A second observation is that for 6 out of 8 cases the mean values indicate the preference for a third-party versus management estimation, associated with a lower audit effort (Table 7, all the panels). But if we look at the statistical significance of these findings, denoted by the simple effects test, it appears that auditors discern between FV provider types only in the case of a strong quality of internal control occurrence (Table 7, Panel B). The explanation is, in our view, that when the quality of the internal control is weak, auditors do not further look into valuation process nuances and detecting new risks, because they have already observed the global risks for the auditee. The statistical significance for the type of valuator appears for the use of Income versus Cost approach, when auditors claim less audit effort, and when the valuation is provided by the management instead of a third-party. This result leads us to believe that auditors do not discern very precisely between the type of valuator (third party or management employee) in correlation with the specificity of valuation process, i.e. FV measurement. Therefore, our initial supposition was also confirmed by the descriptive statistics that revealed a low degree of FV use and audit (as training and missions). We infer that, in the Romanian context, auditors display a moderate understanding of the valuation approaches' content and their technical application. Additionally, companies would rather resort to a FV estimation specialist, often suggested by the auditor, who subsequently heavily relies on the competencies of this experienced and well-known valuation expert. The consequence is that the auditor does not investigate himself, in a proper manner, the valuation process.

A third observation is linked to the two approaches we investigated, income and cost, both as level 3 in the fair value hierarchy, which are little discussed in the context of the audit and the risk of estimation in the literature. The income approach could be more reliable due to its anticipative viewpoint, but at the same time, more volatile and subjective because it is based on predictions. On the 
other side, cost approach is more anchored in the present, sometimes also using historical data, and in the same time subjective because of the need to update the past inputs and the choices for current data on the market. However, for 3 out of 4 cases (in Table 7, Panels A and B), independently of the quality of the internal control, and if we look at the mean values, contrary to our expectations, the income approach is reported as requiring equal or more audit effort than the cost approach. The exception, statistically significant, occurred for the case of a strong internal control quality, in which case the auditors would make a greater effort to verify the approximate cost, and when the estimate is performed by the management, not a third party.

Correlating observations 2 and 3 about the type of valuator and the type of valuation approach, we assert that our prediction P1 is partially verified: Auditors distinguish between the use by the management of a third party versus an internal valuation, and consider that a third party valuation decreases the estimation risk and audit effort, when cost approach is applied instead of income approach for FV measurement and when the internal control is strong. The first part of P1 is validated, but the second reverses the type of valuation approach compared to our prediction.

\section{Conclusions}

Our results based on mean values are in line with those obtained by Brink et al. (2016) who found that the auditors consider the FV estimation less risky if it is generated by an external source. However, even if the mean values confirm that issue, simple effects test do not confirm this preference. Considering Salzsieder's (2016) suggestion that auditors have the tendency to verify in detail the Valuation report when disclosed, our outcomes suggest this is valid in the case of income approach application, when the effort of the auditor is greater than when checking management estimation. Therefore, the choice for a third party, associated with less audit effort and risk of estimation, does not occur in all the scenarios, but under some constraints and only partially for some of the issues of the valuation process.

It seems that the income approach creates greater concern for the Romanian auditors compared to the cost approach. A possible explanation is that the income approach has a more sophisticated (market-linked) viewpoint. But in its essence, this choice is contradictory because the cost approach is more technical (surfaces, technical functionalities, and other engineering aspects), and therefore more incompatible with the expertise typical for the accounting profession. As such, we raise a red flag for auditors, for both approaches based on models, income as well as cost, both incorporating a high degree of complexity. Also, we plead for a more consistent guidance in auditing standards in valuation issues that could improve, in a setting like the Romanian one, the lack of trainings on FV subject matter.

Our results could contribute to the existing literature, firstly by enlarging the discussion on FV estimates audit effort and risk of estimation over the entire process of valuation, not only FV provider, but also FV measurement issues. We confirm that, in specific circumstances, audit additional effort and risk of estimation are smaller for the auditor when FV is estimated by a third party, instead of by the management. These specific circumstances are strong quality of the internal control and a component of FV reporting linked to the valuation methodology. 
Secondly, we opened a new avenue of discussion on the FV estimate issues for non-financial assets (financial assets being usually analysed in relevant papers), particularly, tangible assets, for which the valuation process is even more difficult, prone to risk of estimation, and hence to audit risks as well.

Thirdly, we prove that the quality of the valuation report and process in terms of sufficient description of inputs and approaches and a reasonable volume of valuation data could minimize the audit risk and additional audit effort. There is a prerequisite for this statement, a good understanding of the valuation process by the auditors.

These results could be of interest for the audit profession, as to awareness raising and training on valuation issues. Also, audit, as well as financial reporting regulators could improve their recommendations on technical issues related to property valuation (non-financial assets), especially when it comes to level 3 of FV measurement. For an emergent economic context, this type of assets and this type of valuation (the models, income and cost approaches) are more likely to occur as measurement and disclosure in financial statements, and therefore their fair values are more exposed to audit risks.

Our results should be interpreted in the light of certain limitations. A possible limitation is the exploratory type of the study, i.e. the investigation of the fixed assets valuation process from the perspective of audit risk. Another limitation is related to the sample size used in the experiment.

\section{References}

Abernathy, J., Hackenbrack, K.E., Joe, J.R., Pevzner, M., Wu, Y-J. (2015) Comments of the Auditing Standards Committee of the Auditing Section of the American Accounting Association on PCAOB Staff Consultation Paper, Auditing accounting estimates and fair value measurements, Current Issues in Auditing, C1-C11.

Barth M.E., Clinch G. (1999) Revalued financial, tangible and intangible assets: associations with share prices and non-market-based value estimates, Journal of Accounting Research, 36(Suppl. 1998), 199-232.

Beneish, M.D., Press, E., Vargus, M.E. (2012) Insider trading and earnings management in distressed firms, Contemporary Accounting Research, 29(1), 191-220.

Bolivar M.P.R., Galera A.N. (2012) The role of fair value accounting in promoting government accountability, ABACUS, 48(3), 348-386.

Bratten, B., Gaynor, L.M., McDaniel, L., Montague, N.R., Sierra, G.E. (2013) The audit of fair values and other estimates: the effects of underlying environmental, task, and auditor specific factors, Auditing: A Journal of Practice and Theory, 32(1), 7-44.

Brink A.G., Tang F., Yang L. (2016) The impact of estimate source and social pressure on auditor's fair value estimate choices, Behavioral Research in Accounting, 28(2), 29-40.

Brown-Liburd H., Mason S., Shelton S. (2014) The effect of reliance on third-party specialists under varying levels of internal control effectiveness on the audit of fair value measurements, Working paper, DePaul University and Rutgers, The State University of New Jersey. 
Cannon N.H., Bedard J.C. (2017) Auditing challenging fair value measurements: evidence from the field, Accounting Review, 94(4), 81-114.

Christensen, B.E., Glover, S.M., Wood, D.A. (2012) Extreme Estimation Uncertainty in Fair Value Estimates: implications for audit assurance, Auditing: A Journal of Practice and Theory, 31(1), 127-146.

Deloitte (2010) Springing forward: the eight annual fair value pricing survey, Retrieved April 4, 2018, from

https://www.mfdf.org/images/DirResPDFs/Fair_Value_Survey.pdf.

Deloitte (2017) PCAOB issues proposals to enhance and strengthen requirements for auditing accounting estimates, including fair value, and to address the auditors' use of the work of specialists, Retrieved September 9, 2018 from https://dart.deloitte.com/USDART/resource/af247b55-5032-11e7-883dd924efc3f5af.

Doliya P., Singh J.P. (2016) An interpretive structural modelling approach to analyze the interaction between factors of the fair value measurement audit process, Journal of Emerging Technologies in Accounting, 13(2), 37-48.

Earley C.E., Hoffman V.B., Joe J.R. (2008) Reducing management's influence on auditors' judgments: an experimental investigation of SOX 404 assessments, Accounting Review, 83(6), 1461-1485.

Ettredge M.L., Xu Y., Yi H.S. (2014) Fair value measurement and audit fees: evidence from banking industry, Auditing: a Journal of Practice and Theory, 33(3), 33-58.

Glover, S. M., Taylor, M., Wu, Y. (2014) The gap between auditing experts' performance and regulatory expectations when auditing complex and fair value measurement: causes and potential solutions, Retrieved July 1, 2018 from http://www.audsymp.dept.ku.edu/wp-content/uploads/2014/05/SaturdayPaper-6-by-Glover-Taylor-Wu.pdf.

Glover, S.M., Taylor, M.H., Wu YJ., (2017) Current practices and challenges in auditing fair value measurement and complex estimates: implications for auditing standards and the academy, Auditing: A Journal of Practice and Theory, 36(1), 63-84.

Goncharov I., Riedl E.J., Sellhorn T. (2014) Fair value and audit fees. Review of Accounting Studies, 19, 210-241. https://doi.org/10.1007/s11142-013-9248-5.

Griffin, J.B., (2014) The effects of uncertainty and disclosure on auditors' fair value materiality decisions, Journal of Accounting Research, 52(5), 65-93.

International Auditing and Assurance Standards Board (IAASB) (2017) International Standard on Auditing, Proposed international standard on auditing 540 (Revised), Retrieved September 3, 2018 from

http://www.ifac.org/system/files/publications/files/Proposed-ISA-540-Revised-

Auditing-Accounting-Estimates-and-Related-Disclosures.pdf.

International Auditing and Assurance Standards Board (IAASB) (2018) International Standard on Auditing 540 Revised, Retrieved April 22, 2019 from https://www.ifac.org/system/files/publications/files/ISA-540-Revised-andConforming-Amendments_0.pdf.

International Auditing and Assurance Standards Board (IAASB) (2018) International Accounting Standards, 500, Retrieved August 20, 2018 from https://www.iaasb.org/clarity-center/clarified-standards. 
Joe J.R., Vandervelde S.D., Wu Y.J. (2017) Use of high quantification evidence in fair value audits: do auditors stay in their comfort zone?, Accounting Review, 92(5), 89-116.

King A.M. (2006) Auditing evaluation reports, Valuation Strategies, 9(6), 18-25.

Martin, R.D., Rich J.S., Wilks T J. (2006) Auditing fair value measurement: a synthesis of relevant research, Accounting Horizons, 20(3), 287-303.

Mora A., McGeachin A., Barth M.E., Barker R., Wagenhofer A., Joos P. (2019) Fair Value Accounting: The Eternal Debate - AinE EAA, Symposium, May 2018, Accounting in Europe, 3-19.

Menelaides S.L., Graham L.E., Fischbach G. (2003) The auditor's approach to fair value, Journal of Accountancy, 195(6), 73-76.

Muller K.A., Riedl E.J. (2002) External monitoring of property appraisal estimates and information asymmetry, Journal of Accounting Research, 40(3), 865-881.

Public Company Accounting Oversight Board (PCAOB) (2011) Report on 2010 Inspection of KPMG, Retrieved September 2, 2018 from https://pcaobus.org/Inspections/Reports/Documents/2011_KPMG_LLP_US.pdf.

Public Company Accounting Oversight Board (PCAOB) (2014) Auditing Accounting Estimates and Fair Value Measurements, Staff Consultation Paper. Retrieved August 21, 2018 from http://pcaobus.org/Standards/Pages/SCP_Accounting Estimates_Fair_Value.aspx.

Public Company Accounting Oversight Board (PCAOB) (2017) Auditing Accounting Estimates and Fair Value Measurements, Staff Consultation Paper. Retrieved September 3, 2018 from https://pcaobus.org/Standards/Documents/SCP Auditing_Accounting_Estimates_Fair_Value_Measurements.pdf.

Salzsieder L. (2016) Fair value opinion shopping, Behavioral Research in Accounting, 28(1), 57-66.

Securities and Exchange Commission SEC (2011) Disclosure and corporate governance: financial reporting challenges for 2012, Retrieved September 2, 2018 from

https://www.weil.com/ /media/files/pdfs/weil_alert_sec_cg_january_12.pdf.

Sellhorn T., Stier C. (2018) Fair value measurement for long-lived operating assets: research evidence, European Accounting Review, 1-31.

Standarde de Evaluare a Bunurilor [Assets Valuation Standards](SEV) (2018) ANEVAR, Retrieved September 2, 2018 from http://site2.anevar.ro/sites/ default/files/page-files/standarde_2018.compressed.pdf

Zack M., McKeen J., Singh S. (2009) Knowledge management and organizational performance: an exploratory analysis, Journal of Knowledge Management, 13(6), 392-409.

Zang, A. (2012) Evidence on the trade-off between real activities manipulation and accrual-based earnings management, Accounting Review, 87(2), 675-703. 


\section{Appendix 1. Excerpt from the case material (for the cell A/a)}

\section{1) BACKGROUND}

Agatha Popescu, financial auditor, just arrived at the office of ALPHA, a joint-stock company that owns industrial type properties. It was February 2019 and Agatha had the task of verifying the values of the assets reported in the financial statements at the end of 2018 for ALPHA. Agatha verifies the estimation of fair value required for revaluation, according to IAS 16.

[The case material focuses on one of the real estate of ALPHA, Building 1 (for simplification, the valuation of the related land is ignored)

\section{2) INFORMATION CONCERNING FAIR VALUE AT DECEMBER 31, 2018}

Agatha received from the executive director of ALPHA a valuation report of a consultant (third-party) regarding the value of a real estate, the Building 1. The estimate was classified as Level 3 (IFRS 13)*.

The details of the valuation performed by the valuator, contained in the Valuation Document (Valuation Report), are given in the Case Material which follows.

\section{3) ELEMENTS TO BE OBTAINED BY THE AUDITOR ON THE ESTIMATION}

The estimation of the fair value was made by the valuator of ALPHA, as it appears from the Case Material - Valuation Report.

Suggestions on the elements to be observed in the Valuation Report:

- to take into account the level of estimation: 3 / income approach;

- whether the estimate of fair value was based on rents or quotations of an active market;

- whether the estimate of fair value was based on the quotation of a real estate agency, if it comes from a similar market and if it reflects market conditions...

\section{4) INFORMATION ON INTERNAL CONTROL}

Before deciding on the risk of estimating fair value, Agatha integrates the conclusions of the entire audit team regarding the internal control of ALPHA. The evaluation of internal control based on the specific stages of the audit leads to the idea that it has a low quality (week internal control).

\section{5) CONCLUSIONS ON THE ESTIMATION OF THE VALUE}

Agatha expresses her conclusions regarding the risk of estimating the value for her audit mission. To do this, she makes two observations and uses the Likert scale to position her opinion. 
A. Likelihood that the auditor (Agatha) will make additional efforts to verify in more detail how to estimate fair value

\begin{tabular}{|l|l|l|l|l|l|l|}
\hline 1 & 2 & 3 & 4 & 5 & 6 & 7 \\
\hline & & & & & & \\
\hline
\end{tabular}

Where 1 - very low likelihood of making extra effort; 7 - very high likelihood of making extra effort

B. Higher risk of misstatement in FV estimation made by the auditor (Agatha)

\begin{tabular}{|l|l|l|l|l|l|l|}
\hline 1 & 2 & 3 & 4 & 5 & 6 & 7 \\
\hline & & & & & & \\
\hline
\end{tabular}

Where 1 - very low likelihood of estimation risk occurrence; 7 - very high likelihood of estimation risk occurrence

*This excerpt from a case material (taken as an example, one between 16 different case materials) is a one-page preamble that explains the context to the auditors. The preamble continued with the valuation document (as appropriate, third party Valuation report or Management's valuation worksheet) in which the auditor noted the assessment made by the valuator and recognized how was apply a specific approach: income or cost. 


\section{Appendix 2. Excerpt from the manipulation checks}

Recognize, according to the descriptions below, without making any calculation, for the Ski Unit (Level ......), and then for the Accommodation Unit (Level .....), the fair value levels, according to the IFRS 13 hierarchy. Then indicate for each Unit the source of the estimate: Ski Unit - source ; Accommodation Unit - source...

\begin{tabular}{|l|l|}
\hline \multicolumn{1}{|c|}{ Value levels } & \multicolumn{1}{c|}{ Source of estimation } \\
Level 1 & $\begin{array}{l}\text { Internal } \\
\text { Data provided by the company: } \\
\text { Market approach from the valuation methodology } \\
\text { management/specialized personnel } \\
\text { Level 2 }\end{array}$ \\
$\begin{array}{l}\text { Market comparisons with similar assets } \\
\text { Market approach from the valuation methodology } \\
\text { Devel 3 }\end{array}$ & $\begin{array}{l}\text { Data provided by an external source/ } \\
\text { consultant }\end{array}$ \\
$\begin{array}{l}\text { Valuation models } \\
\text { Approaches from the valuation methodology: }\end{array}$ & \\
income, cost & \\
\hline
\end{tabular}

Stela lonescu, chief accountant for GROUP BETA was sent on July $20 \times 8$ to the offices of GAMMA, one of BETA's subsidiaries. Although GAMMA seemed a promising acquisition two years ago, the below average snowfall and the current crisis in the real estate market have seriously affected the initial successful projections. As a result, Stela's mission was to evaluate assets to detect potential impairment.

GAMMA activities are divided into two Units: Ski and Accommodation. Each Unit represents a separate business, so that each one's cash flows are largely independent of the other Units. Stela will then determine the fair value for each Unit.

The Ski Unit earns revenue from the sale of lift tickets and other services, such as ski and snowboard lessons, equipment rentals and other recreational activities. Stela consulted with a local valuator who told her that, although there are no business units identical to the GAMMA ski resort, two other very similar ski areas were sold in the last year. Stela will use these sales to calculate a multiple (applied to sales revenue) and estimate the value of GAMMA's Ski Unit. Comparable sales are: Piatra Craiului Mountain, which generated average annual sales revenue of $\$ 6,500,000$, was sold for $\$ 11,375,000$; and Predeal Resort, which generated average annual sales revenue of $\$ 13,000,000$, was sold for $\$ 22,750,000$. GAMMA generated average annual sales revenue of $\$ 5,500,000$.

The Accommodation Unit ...... 